\title{
Review on gall bladder myeloid sarcoma: a great masquerader
}

\author{
Kamal Kant Sahu ${ }^{1}$, Santosh Rajaram Kale ${ }^{2}$, Ahmad Daniyal Siddiqui ${ }^{1}$ \\ ${ }^{1}$ Hemato-Oncology Division, Department of Internal Medicine, Saint Vincent Hospital, Worcester, MA, USA; ${ }^{2}$ Department of Internal Medicine, \\ Nassau University Medical Center, East Meadow, New York, USA \\ Contributions: (I) Conception and design: All authors; (II) Administrative support: All authors; (III) Provision of study materials or patients: All \\ authors; (IV) Collection and assembly of data: All authors; (V) Data analysis and interpretation: All authors; (VI) Manuscript writing: All authors; (VII) \\ Final approval of manuscript: All authors. \\ Correspondence to: Dr. Kamal Kant Sahu. Hemato-Oncology Division, Department of Internal Medicine, Saint Vincent Hospital, 123 Summer Street, \\ Worcester, MA, USA. Email: drkksahu85@gmail.com.
}

\begin{abstract}
Pain in abdomen has wide differentials and narrowing down the clinical possibilities depends on type of pain, location, characterization which is usually assisted by imaging studies. Cholecystitis and cholelithiasis are amongst the common causes of acute abdomen. This study reviews the literature for the clinical characteristics, differential diagnosis, treatment and prognosis of reported cases of gallbladder myeloid sarcoma (GB-MS) who presented with abdominal symptoms. A total of 17 cases of GB-MS were studied. The median age was 52 years with age range of 23 to 84 years. All except 1 patient presented with abdominal symptoms. Based on imaging or pathological studies, 3 cases were initially confused with gallbladder lymphoma or cancer. Only 5 patients were treated with AML like chemotherapy. Treatment given included combinations of surgery, chemotherapy, and radiotherapy. None of the cases underwent HSCT for GB-MS. Seven patients were alive till the time of last F/U, 9 succumbed to death while F/U of 1 patient was not available. Irrespective of treatment protocol followed suggesting the poor prognosis in GB-MS cases. In conclusion, acute abdomen complicating blood malignancies is life threatening and can be devastating if not detected and treated in a timely fashion.
\end{abstract}

Keywords: Acute abdomen; myeloid sarcoma (MS); acute myeloid leukaemia (AML); chemotherapy; gallbladder

Submitted Nov 21, 2019. Accepted for publication Mar 14, 2020.

doi: 10.21037/cco-19-250

View this article at: http://dx.doi.org/10.21037/cco-19-250

\section{Introduction}

Acute abdomen is one of the frequently encountered scenario in emergency room. Cholecystitis and cholelithiasis are amongst the common causes of acute abdomen. Approximately $5 \%$ of patients with acute leukemia can have acute abdomen due to variety of reasons (1). Term "Granulocytic sarcoma (GS)" was coined by Rappaport et al. in 1966, also commonly known as myeloid sarcoma (MS) and referred to as extramedullary solid deposits, found either in isolation or in association with leukemias. Most commonly, it has been reported to be associated with acute myeloid leukemia (AML). Other hematological conditions like myelodysplastic syndrome (MDS), chronic myelogenous leukemia (CML), acute lymphoblastic leukemia (ALL), and myelofibrosis (MF) are also reported to have leukemic deposits. MS commonly involves lymph nodes, skin, head and neck region, and orbit although almost any site may be involved (2-13). Gastrointestinal involvement is very rare site of MS. Gallbladder is even more rare to involve and often confused with other common gallbladder pathologies like cholecystitis, gallbladder cancer etc.

Clinically, depending on the time of occurrence, MS is categorized in three different groups as follows: (I) concurrent, when primary hematological disease and MS is diagnosed at the same time; (II) isolated, when MS is the sole finding without any evidence of leukemia/ MPN etc.; (III) secondary, when MS develops in a known case of leukemia/MPN signifying either as a relapse or extramedullary blast crisis. 


\section{Methodology}

A comprehensive search strategy was devised by two independent researchers. By using a combination of the medical subject heading $(\mathrm{MeSH})$ terms "gallbladder and myeloid sarcoma", "gallbladder and Chloroma", "gallbladder and granulocytic sarcoma", we searched the Ovid MEDLINE and Ovid Embase along with relevant citations between 1946 and 2019. English as a language restriction was applied and abstract and title of the all the citations were screened. Ultimately, the search showed in total 17 cases of myeloid leukemic infiltration of gallbladder.

\section{Results}

\section{Patient characteristics}

In total, we included 17 cases in our study cohort. Patient's age, sex, clinical presentations, and laboratory data are shown in Table 1. Of the 17 total patients, the median age was 52 years old with age range of 23 to 84 years.

\section{Diagnostic challenges}

Based on imaging or pathological studies, 3 cases were initially confused with gallbladder lymphoma or cancer. Later, review of the case confirmed them as gallbladder myeloid sarcoma (GB-MS) (14-16).

\section{Other sites of involvement by leukemic infiltrates}

We also reviewed other sites of involvement by leukemic infiltrates apart from gallbladder. We found MS involvement in pancreas, stomach, common bile duct, omental bursa, liver, cystic duct, lymph node and so on (Table S1).

\section{Categorizations of TMS}

By analyzing the clinical data, we divided the patients to either concurrent GB-MS cases (4 cases), isolated GBMS cases (5 cases) and secondary GB-MS cases (8 cases). In patients with secondary and concurrent GB-MS, the underlying diseases were AML (5 cases), MF (4 cases), 2 CML (2 cases) and MDS (1 case).

\section{Treatment strategies and outcome}

Different authors treated their patients with different regimens including various combinations of cholecystectomy, chemotherapy and radiotherapy. Table $S 1$ mentions different regimens used for treatment of GB-MS which clearly points to the fact that there is no unifying protocol driven treatment guidelines till now. Table $S 1$ also mentions in detail the follow up details about the patients. Analysis also showed that $56.25 \%$ patients died during the same hospitalization or at follow up. Reasons were variable, sepsis, multiorgan failure, DIC, or disease progression.

\section{Discussion}

The available literature with regards to leukemic involvement of gastrointestinal tract has been known since long (16). The gastrointestinal tract is otherwise a rare site of MS involvement. Due to rarity, the exact frequency is relatively unknown. However, few autopsy series evaluating patients dying during acute phase of acute leukemia (both lymphocytic and myelocytic) have reported gastrointestinal tract involvement to be variable and anywhere ranging from $13 \%$ to $63 \%$ (17).

\section{Diagnostic dilemma for ER physicians}

As depicted in our study, GB-MS can be easily confused with benign conditions like cholecystitis, cholangitis or malignant conditions like adenocarcinoma. Though GBMS is a rare entity, but ER physicians should always keep it in mind while evaluating any case of right upper quadrant pain or obstructive jaundice especially with a background history of myeloid leukemia or abnormal cells in peripheral circulation. Menasce et al. reported that almost in $75-86 \%$ nonleukemic patients, MS were initially misdiagnosed. Our review also shows the similar results which underscores the importance of educating ER physicians about this rare entity (18).

\section{Other malignant differential diagnosis for acute abdomen/ cholecystitis}

There are various close differentials to GB-MS like: nonHodgkin's lymphoma (NHL), Ewing's sarcoma, primitive neuroectodermal tumors, high risk small cell type stromal tumors, eosinophilic granuloma, and undifferentiated small cell lung cancer (18). Microscopically, MS cells can be easily confused with lymphoma cells. MS blast cells have acidophilic cytoplasm and are positive for CD 117, MPO and CD 43. Cytogenetic abnormalities like inv chromosome 16, t (8:21), lack of Auer rods, FAB M2, M4, M5 and 


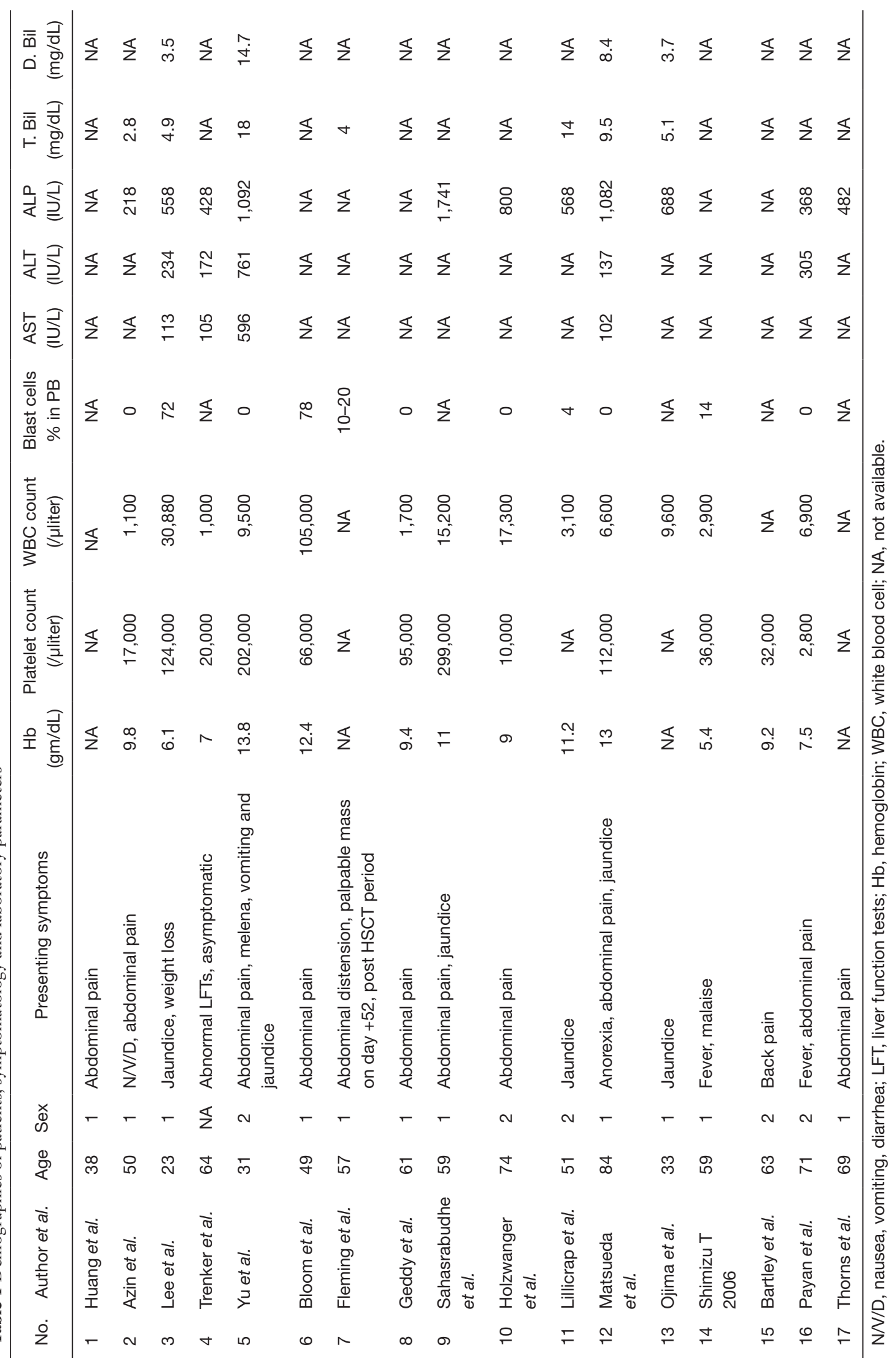


CBFB/MYH 11 fusion gene have been associated with high incidence of MS (19).

\section{Clinical presentation}

Basically, the symptomatology in GI based MS is variable and depends on the site of location. As evident in our study, in all cases, GB-MS presented with non-specific symptoms of cholecystitis. It is almost impossible to diagnose GB-MS without histopathological evaluation in naïve cases except in conditions when there is already a known history of hematological malignancy or presence of frank circulating blast cells to lead the physicians. This fact emphasizes the need for ER physicians to quickly scan patient's history for hematological malignancy which will help start evaluating the patient from day 1 itself for GB-MS which will save previous time.

Ultrasound of abdomen (USG) and CT abdomen are two major supplementary diagnostic modalities. Best specimen to diagnose GB-MS would be histopathological study of the resected gall bladder. In case of simultaneous biliary tract involvement, ERCP and cytology of exfoliated cells may assist in diagnosing additional sites of MS involvement. Recently, Matsueda et al. reviewed MS cases presenting with obstructive jaundice (15). In all cases, the site of infiltration was reported as biliary tract or head of pancreas. Azin et al.'s case had multiple hospitalizations for recurrent cholecystitis (20). After approximately 7 weeks of the initial presentation, patient underwent elective cholecystectomy and was diagnosed with GB-MS. Although, the course of therapy did not change as patient denied any further chemotherapy however an early diagnosis and surgical interventions could have at least improved the quality of life of the patient (20). Hunter et al. studied gastrointestinal complications of leukemia (142 patients) while undergoing chemotherapy and reported that $9 \%$ had abdominal symptoms with only 1 case of MS involving common bile duct (21).

Hence for a comprehensive and timely diagnosis, a combined diagnosed strategy including imaging studies, ERCP, histopathology, and immunohistochemistry are the necessary requirements. Accurate diagnosis becomes more daunting in post HSCT patients due to other concomitant complexities like graft versus host disease (GVHD), immunosuppressive drug related adversities like cholestasis, opportunistic infections, sinusoidal obstruction syndrome (SOS), acalculous cholecystitis and so on (22). Approximately $5 \%$ of patient's undergoing chemotherapy for leukemia developed cholecystitis in one series (23).
Background information can play a crucial role especially in emergency room. In our review, there were 12 cases (70.58\% of study cohort) who had associated hematological malignancy (5 AML, $4 \mathrm{MF}, 2 \mathrm{CML}$ and $1 \mathrm{MDS}$ case). It is expected to have a higher probability of having GB-MS with cancer background when compared to those without cancer history. Scully et al.'s case was challenging as the 47-year-old had history of both colon cancer and AML thereby keeping both differentials as the possibility during evaluation of the abdominal pain and obstructive jaundice in their case (24). Microscopic evaluation of the surgical specimen confirmed it to be leukemic infiltration of common bile duct (24). Hence, sometimes despite the best clinical judgement, only the specimen examination confirms the diagnosis. Our review showed 5 cases out of 17 to have isolated GB-MS without any bone marrow involvement (14,25-28). Bartley et reported an interesting case of disseminated extramedullary myeloid tumor of the gallbladder but without involvement of the bone marrow (28).

\section{Management and prognosis}

Conventionally the prognosis of MS is extremely poor. Untreated MS cases usually transform to frank leukemia within 6-12 months (29). With regards to the treatment, surgical resection like cholecystectomy serves purpose for not only immediate relief to the patient but also provides specimen for definitive diagnosis. However, cholecystectomy is not a definitive treatment for GB-MS and cannot delay the transformation to leukemia or prevent the progression of disease unless chemotherapy is initiated soon (30). This is based on the expert opinion that suggests treating primary or isolated GB-MS just like any systemic AML disease. Hence, hematology opinion should be sorted for the patient care as soon as the diagnosis is established. Also, important to note that in general any surgery in patients with leukemia are associated with high mortality rates (31). Although, there has been significant improvement in survival in last few decades, most of the non-cancer related deaths are reported to result from uncontrolled sepsis (32-34). The current literature supports the use of systemic antileukemic therapy followed by HSCT as soon as possible in order to control the progression and improve the prognosis $(26,35,36)$.

\section{Conclusions}

In conclusion, MS involving gallbladder and nearby organs 
is extremely rare and tends to be misdiagnosed. Awareness of this entity amongst the ER physicians, surgeons and hospitalists is of utmost importance. Despite the exponential advancement in the management, prognosis is still dismal and further RCTs are need of hour to improve survival of patients.

\section{Acknowledgments}

Funding: None.

\section{Footnote}

Conflicts of Interest: All authors have completed the ICMJE uniform disclosure form (available at http://dx.doi.org/ cco-19-250). The authors have no conflicts of interest to declare.

Ethical Statement: The authors are accountable for all aspects of the work in ensuring that questions related to the accuracy or integrity of any part of the work are appropriately investigated and resolved.

Open Access Statement: This is an Open Access article distributed in accordance with the Creative Commons Attribution-NonCommercial-NoDerivs 4.0 International License (CC BY-NC-ND 4.0), which permits the noncommercial replication and distribution of the article with the strict proviso that no changes or edits are made and the original work is properly cited (including links to both the formal publication through the relevant DOI and the license). See: https://creativecommons.org/licenses/by-nc-nd/4.0/.

\section{References}

1. Hawkins JA, Mower WR, Nelson EW. Acute abdominal conditions in patients with leukemia. Am J Surg 1985;150:739-42.

2. Sahu KK, Mishra AK, Lal A. Advancements in Treatment of Refractory and Relapsed Myeloid Sarcoma. J Oncol Pract 2019;15:622-3.

3. Sahu KK, Lal A, Mishra AK. Myeloid sarcoma of central nervous system: Approach and management. J Clin Neurosci 2019;70:267-8.

4. Sahu KK, Sherif AA, Mishra AK, et al. Testicular Myeloid Sarcoma: A Systematic Review of the Literature. Clin Lymphoma Myeloma Leuk 2019;19:603-18.

5. Sahu KK, Thakur K. Role of Positron Emission
Tomography Imaging in Myeloid Sarcoma. Indian J Nucl Med 2018;33:90.

6. Gautam A, Jalali GK, Sahu KK, et al. Cardiac Myeloid Sarcoma: Review of Literature. J Clin Diagn Res 2017;11:XE01-4.

7. Sahu KK, Gautam A, Ailawadhi S. Re: FDG PET/CT Findings of Intracardiac Myeloid Sarcoma. Clin Nucl Med 2017;42:242-5.

8. Sahu KK, Dhibar DP, Malhotra P. Isolated myeloid sarcoma. Orbit 2016;35:351.

9. Sahu KK, Jain A, Yanamandra U, et al. Myeloid Sarcoma of Vulva: A Short Update. Indian J Hematol Blood Transfus 2016;32:69-71.

10. Sahu KK, Yanamandra U, Malhotra P. Orbital myeloid sarcoma: Rare presentation of AML. Orbit 2016;35:157-8.

11. Sahu KK, Malhotra P. Re: "Granulocytic Sarcoma of the Orbit Presenting as a Fulminant Orbitopathy in an Adult with Acute Myeloid Leukemia". Ophthalmic Plast Reconstr Surg 2015;31:421.

12. Jain A, Sahu KK, Sharma S, et al. Shoulder Myeloid Sarcoma: An Initial Presentation of CML Blast Crisis. Indian J Hematol Blood Transfus 2016;32:361-3.

13. Sahu KK, Tyagi R, Law AD, et al. Myeloid Sarcoma: An Unusual Case of Mediastinal Mass and Malignant Pleural Effusion with Review of Literature. Indian J Hematol Blood Transfus 2015;31:466-71.

14. Ojima H., Hasegawa T., Matsuno Y, et al. Extramedullary myeloid tumour (EMMT) of the gallbladder. J Clin Pathol 2005;58:211-3.

15. Matsueda K, Yamamoto H, Doi I. An autopsy case of granulocytic sarcoma of the porta hepatis causing obstructive jaundice. J Gastroenterol 1998;33:428-33.

16. Bloom SH, Coad JE, Greeno EW, et al. Cholecystitis as the presenting manifestation of acute myeloid leukemia: report of a case. Am J Hematol 2002;70:254-6.

17. Kirshbaum JD, Preuss FS. Leukemia; clinical and pathologic study of 123 fatal cases in a series of 14,400 necropsies. Arch Intern Med 1943;71:777-92.

18. Menasce LP, Banerjee SS, Beckett E, et al. Extramedullary myeloid tumor (granulocytic sarcoma) is often misdiagnosed: a study of 26 cases. Histopathology 1999;34:391-8.

19. Shimizu T, Tajiri T, Akimaru K, et al. Cholecystitis caused by infiltration of immature myeloid cells: a case report. J Nippon Med Sch 2006;73:97-100.

20. Azin A, Racz JM, Jimenez MC, et al. Relapse of acute myeloid leukemia manifested by cholecystitis: A case report and review of the literature. Int J Surg Case Rep 
2014;5:302-5.

21. Hunter TB, Bjelland JC. Gastrointestinal complications of leukemia and its treatment. AJR Am J Roentgenol 1984;142:513-8.

22. Fleming DR, Slone SP. CML blast crisis resulting in biliary obstruction following BMT. Bone Marrow Transplant 1997;19:853-4.

23. Gorschlüter M, Marklein G, Hofling K, et al. Abdominal infections in patients with acute leukaemia: a prospective study applying ultrasonography and microbiology. Br J Haematol 2002;117:351-8.

24. Case Records of the Massachusetts General Hospital (Case 32-1988). N Engl J Med 1988;319:356-64.

25. Huang XL, Tao J, Li JZ, et al. Gastric myeloid sarcoma without acute myeloblastic leukemia. World J Gastroenterol 2015;21:2242-8.

26. Yu T, Xu G, Xu X, et al. Myeloid sarcoma derived from the gastrointestinal tract: A case report and review of the literature. Oncol Lett 2016;11:4155-9.

27. Holzwanger EA, Alam Z, Hsu E, et al. A Case of Granulocytic Sarcoma or Extramedullary Acute Myelomonocytic Leukemia of the Gallbladder. Am J Case Rep 2018;19:1262-6.

28. Bartley AN, Nelson CL, Nelson DH, et al. Disseminated extramedullary myeloid tumor of the gallbladder without involvement of the bone marrow. Am J Hematol

Cite this article as: Sahu KK, Kale SR, Siddiqui AD. Review on gall bladder myeloid sarcoma: a great masquerader. Chin Clin Oncol 2020;9(3):37. doi: 10.21037/cco-19-250
2007;82:65-8.

29. Yamauchi K, Yasuda M. Comparison in treatments of nonleukemic granulocytic sarcoma: report of two cases and a review of 72 cases in the literature. Cancer 2002;94:1739-46.

30. He J, Zhu L, Ye X, et al. Clinical characteristics and prognosis of nonleukemic myeloid sarcoma. Am J Med Sci 2014;347:434-8.

31. Björnsson S, Yates JW, Mittelman A, et al. Major surgery in acute leukemia. Cancer 1974;34:1272-5.

32. Vaughn EA, Key CR, Sterling WA Jr. Intraabdominal operations in patients with leukemia. Am J Surg 1988;156:51-3.

33. Yanamandra U, Sahu KK, Khadwal A, et al. Recurrent Sweet's Syndrome in a Case of AML. Indian J Hematol Blood Transfus 2016;32:82-5.

34. Sahu KK, Mishra K, Malhotra P. Extramedullary deposits in leukemia: Out of blood but not out of mind. J Microsc Ultrastruct 2019;8:35-6.

35. Sahu KK, Prakash G, Sanamandra P, et al. An Unusual Site of Acute Lymphoblastic Leukaemia Relapse: Challenge for Gynaecologists. J Obstet Gynaecol India 2016;66:656-61.

36. Sahu KK, Malhotra P, Uthamalingam P, et al. Chronic Myeloid Leukemia with Extramedullary Blast Crisis: Two Unusual Sites with Review of Literature. Indian J Hematol Blood Transfus 2016;32:89-95. 
Table S1 Shows background information, type of GB-MS, treatment regimen received with F/U da

\begin{tabular}{|c|c|c|c|c|c|c|c|c|c|c|}
\hline Author et al. & Basic disease/background & Radiographic findings & Surgery performed & $1 / \mathrm{S} / \mathrm{C}$ & Primary disease & Other MS sites & $\begin{array}{l}\text { Blast cell \% in BM Bx at the } \\
\text { time of diagnosis of MS }\end{array}$ & Chemotherapy for MS & HSCT & Outcome \\
\hline Huang et al. & No cancer & $\begin{array}{l}\text { CT: pancreatitis and intrahepatic and } \\
\text { extrahepatic bile duct dilation }\end{array}$ & No, UGIE showed gastric MS & 1 & Not applicable & $\begin{array}{l}\text { Pancreas, stomach, common bile } \\
\text { duct, RPLN, omental bursa, skeleton }\end{array}$ & 0 & $\begin{array}{l}\text { Induction (IDA + ARA-C) followed by } \\
\text { consolidation }\end{array}$ & No & $\begin{array}{l}\text { Alive, till 1-year f/u, patient alive and disease in } \\
\text { remission }\end{array}$ \\
\hline Azin et al. & $\begin{array}{l}\text { CML with myeloid blast crisis, received } \\
\text { induction chemotherapapy (AArac- IDAN) } \rightarrow \\
\text { relapsed } \rightarrow \text { re-induction NoVE-HiDAC } \\
\text { achieved remission and was waiting for HSCT }\end{array}$ & $\begin{array}{l}\text { Galllbadder distension and thickening } \\
\text { consistent with cholecystitis }\end{array}$ & Cholecystectomy & $\mathrm{s}$ & $\begin{array}{l}\text { CML with myeloid blast } \\
\text { crisis in remission (BM- } \\
\text { no blast cells) }\end{array}$ & None & Yes, details NA & None & No & $\begin{array}{l}\text { Alive, patient denied any further chemotherapy } \\
\text { and was in remission till } 5 \text { months of follow up }\end{array}$ \\
\hline Lee et al. & No cancer & $\begin{array}{l}\text { Hepatosplenomegaly, mild dilatation of } \\
\text { intrahepatic bile ducts and mild distension } \\
\text { of the gallbladder }\end{array}$ & None & c & AML & No & 75.60 & $\begin{array}{l}\text { Induction chemotherapy (cytarabine and } \\
\text { idarubicin) }\end{array}$ & No & $\begin{array}{l}\text { Alive, patient continued to receive consolidation } \\
\text { till last follow up }\end{array}$ \\
\hline Trenker et al. & AML, M5 & $\begin{array}{l}\text { USG: enlarged, wall-accented gallbladder } \\
\text { with intraluminal echogenic sludge and } \\
\text { small nodules in the wall }\end{array}$ & $\begin{array}{l}\text { Cholecystectomy and } \\
\text { percutaneous biliary drainage }\end{array}$ & $\mathrm{s}$ & AML, M5 & Cystic duct & No & NA & NA & NA \\
\hline Yuetal. & No evidence of cancer & $\begin{array}{l}\text { CT: mass in the gastric antrum area, } 5.2 \mathrm{~cm} \\
\times 6.2 \mathrm{~cm} \text { in size, with possible infiltration } \\
\text { of the duodenum, gallbladder and head of } \\
\text { the pancreas, and possible retroperitoneal } \\
\text { lymph node metastasis }\end{array}$ & $\begin{array}{l}\text { Percutaneous transhepatic } \\
\text { cholangial drainage and gastric } \\
\text { mucosal biopsy }\end{array}$ & 1 & Not applicable & $\begin{array}{l}\text { Stomach, duodenum, gallbladder and } \\
\text { head of the pancreas, and possible } \\
\text { retropertitoneal Iymph node metastasis }\end{array}$ & 0 & Radiotherapy (total dose $2,450 \mathrm{cGy}$ ) & No & $\begin{array}{l}\text { Died. Disease progression with new MS lesions } \\
\text { involving breast and orbitsts. Subsequently, } \\
\text { patitent received induction (IDAA ARA-C), } \\
\text { followed by consolidation and HSCT. In } \\
5 \text { months, disease relapsed, for which he } \\
\text { received HAG regimen and DLI but died due to } \\
\text { disease progression }\end{array}$ \\
\hline Bloom et al. & No evidence of cancer & $\begin{array}{l}\text { HIDA scan: revealed impaired gall bladder } \\
\text { emptying }\end{array}$ & Cholecystectomy & c & AML, M4 & $\begin{array}{l}\text { Mesenteric } L N \text {, sacral root infiltrates } \\
\text { and pancreatic mass }\end{array}$ & No & $\begin{array}{l}\text { Two sessions of leukapheresess and Induction } \\
\text { therapy y didarubicin and cctarababine) followedd } \\
\text { by } 3 \text { consolidation cycles. Till } 19 \text { months } f / \text {, } \\
\text { patient is in remission }\end{array}$ & None & $\begin{array}{l}\text { Alive and in remission for } 19 \text { months after the } \\
\text { induction therapy till last } F / U\end{array}$ \\
\hline Fleming et al. & $\begin{array}{l}\text { CMLL, post HSCT with post-transplant } \\
\text { complications-GVHD, CMV pneumonia }\end{array}$ & $\begin{array}{l}\text { CT scan: revealed distended gall bladder } \\
\text { and HIDA scan revealed ductal obstruction }\end{array}$ & Cholecystectomy & $\mathrm{s}$ & Yes & Cystic duct & 30 & $\begin{array}{l}\text { Immunosuppression withdrawn, cyclosporine } \\
\text { discontinued, and prednisone tapered }\end{array}$ & No & $\begin{array}{l}\text { Died due to respiratory failure on } 59 \text { th day after } \\
\text { HSCT }\end{array}$ \\
\hline Geddy et al. & No evidence of cancer & USG: small gallstone in gall bladder & Cholecystectomy & c & MF & No & Yes (blast cells not mentioned) & No & No & $\begin{array}{l}\text { Died. After } 2 \text { months, patient developed frank } \\
\text { AML and died due to progression of disease }\end{array}$ \\
\hline $\begin{array}{l}\text { Sahasrabudhe } \\
\text { et al. }\end{array}$ & Myelofibrosis for last 4 years & USG: gallstones; ERCP: dilated bile duct & ERCP and removal of stones & $\mathrm{s}$ & MF & No & No & No & No & $\begin{array}{l}\text { Alive, at follow-up after } 7 \text { months, patient } \\
\text { underwent cholecystectomy and doing well }\end{array}$ \\
\hline $\begin{array}{l}\text { Holzwanger } \\
\text { et al. }\end{array}$ & No evidence of cancer & $\begin{array}{l}\text { USG: cholelithiasis and thickened gall } \\
\text { bladder; ERCP: stone in common bile duct }\end{array}$ & Cholecystectomy & 1 & None & None & None & No & No & $\begin{array}{l}\text { Died. Family requested for comfort measures } \\
\text { only as antitent continued to deteriorate due to } \\
\text { sespis and died soon }\end{array}$ \\
\hline Lillicrap et al. & $\begin{array}{l}\text { Was evaluated for anemia and } \\
\text { thrombocytopenia, and was diagnosed as } \\
\text { AML M2 tor which hhe received induction } \\
\text { chemotherapy (Ara-C, TG, DNR) f/l } \\
\text { maintenance chemotherapy (BCNU and } \\
\text { cyclophosphamide) when she developed } \\
\text { jaundice }\end{array}$ & $\begin{array}{l}\text { CT scan: large mass in head of pancreas } \\
\text { with no gallstones }\end{array}$ & Cholecystectomy & $\mathrm{s}$ & $\begin{array}{l}\text { AML-M2, active disease } \\
\text { (BM-70\% blast cells) }\end{array}$ & Cystic duct and RPLN & 70 & Yes, initiated details NA & No & $\begin{array}{l}\text { Died within } 2.5 \text { weeks due to acute } \\
\text { hemorrhagic pneumonia }\end{array}$ \\
\hline $\begin{array}{l}\text { Matsueda } \\
\text { et al. }\end{array}$ & $\begin{array}{l}\text { She was evaluated } 18 \text { months ago for right } \\
\text { inguinal lymphadenopathy-biopsied and } \\
\text { diagnosed as chronic lymphadenitis }\end{array}$ & $\begin{array}{l}\text { USG: GB thickening and mass; CT scan: } \\
\text { low density mass a the porta hepatis } \\
\text { and thickening of the gall bladder; ERCP: } \\
\text { stricture common hepatic ducts and } \\
\text { dilatatation of the intrahepatic bile ducts }\end{array}$ & $\begin{array}{l}\text { Conservative with stent } \\
\text { placement and antibiotics }\end{array}$ & c & $\begin{array}{l}\text { AML-Mo, active disease } \\
\text { (BM-blast cell) }\end{array}$ & $\begin{array}{l}\text { Confirmed post-mortem: porta } \\
\text { hepatis, liver, spleen, Iymph node, } \\
\text { heart, lungs, kidnney, testis, brainstem }\end{array}$ & 88.40 & No, as diagnosed at postmortem & No & $\begin{array}{l}\text { Died. ERCP + stent placement. Initial diagnosis } \\
\text { was suspected as galllbladder carcinoma and } \\
\text { family opted for supportive care. After } 1 \text { month, } \\
\text { he was diagnosed with AML-MO and he died, } \\
\text { due to DCC. Diagnosis Ao GMS was made } \\
\text { during postmortem period }\end{array}$ \\
\hline Ojima et al. & No evidence of cancer & $\begin{array}{l}\text { Abdominal computed tomography imaging } \\
\text { showed partial infiltration of the tumor into } \\
\text { the GB wall }\end{array}$ & Hepatopancreatoduodenectomy & 1 & No & $\begin{array}{l}\text { Cystic duct, CBD, portal vein, liver, } \\
\text { hepatodudodenal ligament, omentum, } \\
\text { transverseds colon and duododenum }\end{array}$ & $0 \%$ & Yes, regimen not available & No & Alive 4 years later, in remission \\
\hline $\begin{array}{l}\text { Shimizu T } \\
2006\end{array}$ & MDS & $\begin{array}{l}\text { USG and CT scan: GB wall thickening, gall } \\
\text { stone, intrahepatic bile duct dilation }\end{array}$ & Open cholecystectomy & s & MDS & No & No & No & No & $\begin{array}{l}\text { Died. Within } 2 \text { weeks of surgery, disease } \\
\text { progressed to frank levkemia for which } \\
\text { chemotherapy (details not available) was } \\
\text { started but patient died due to sever } \\
\text { pneumonia, DIC and multiorgan failure }\end{array}$ \\
\hline Bartley et al. & No evidence of cancer & CT: e/o cholangitis & Cholecystectomy & 1 & No & $\begin{array}{l}\text { Confirmed post-mortem: myocardium, } \\
\text { lungs, kidney, pancreas, thyroid, } \\
\text { pararthyroid, adrenal gland }\end{array}$ & $\begin{array}{l}0 \% \text { in BM examination at } \\
\text { postmortem }\end{array}$ & $\begin{array}{l}\text { No, patient died after cholecystectomy } \\
\text { during post-operative period }\end{array}$ & No & $\begin{array}{l}\text { Died. Postoperatively, the patient experienced } \\
\text { respiratory distress requiring intubation and } \\
\text { died of multiorgan failure }\end{array}$ \\
\hline Payan et al. & Recently diagnosed myelofibrosis & USG: thickened GB wall & Laproscopic cholecystectomy & s & MF & Liver, cystic duct, Iymph node & $\begin{array}{l}\text { Distress requiring intubation } \\
\text { and died of multiorgan failure }\end{array}$ & & & $\begin{array}{l}\text { Died, within } 6 \text { weeks due to leukemic } \\
\text { conversion }\end{array}$ \\
\hline Thorns et al. & Myelofibrosis & USG: gallstones & Cholecystectomy & s & MF & No & 0 & No & No & $\begin{array}{l}\text { Alive, } 11 \text { months } F / U, \text { no leukemic } \\
\text { transformation, disease stable }\end{array}$ \\
\hline
\end{tabular}

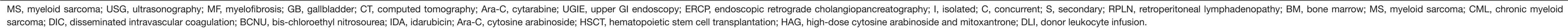

